DOI 10.1515/linpo-2017-0012

\title{
Quantification and definiteness/indefiniteness: integration and functional identity of semantic categories
}

\author{
Aleksander Kiklewicz \\ Department of Journalism and Social Communication, University of Warmia and Mazury in Olsztyn \\ aleksander.kiklewicz@uwm.edu.pl
}

\begin{abstract}
Aleksander Kiklewicz. Quantification and definiteness/indefiniteness: integration and functional identity of semantic categories. The Poznan Society for the Advancement of the Arts and Sciences, PL ISSN 0079-4740, pp. $53-68$

The reference theory popular in 1970-1990s, which aimed at integrating various forms of semantic determination of lexical units of the language analysed from the syntax perspective, provides the starting point for the author. Quantification and definiteness/indefiniteness were treated in numerous publications from that period as varieties of the same semantic category, i.e. determination of the referential status of nominal groups. The author assumes that both categories demonstrate functional independence, therefore their exponents form opposites. Consequently, the quantification model of definiteness/indefiniteness, cultivated by some researchers, is not supported in the language material, being rather a strictly logical structure. At the same time, the author demonstrates that certain relations and dependencies occur between the two categories. Four aspects of such dependencies: selection, implication, collocation and derivation, are examined in the paper using Polish language materials and materials of other European languages.
\end{abstract}

Keywords: semantics, semantic category, semantic determination, quantification, determinacy vs. indeterminacy, reference

1. The subject of the paper is functional cooperation between two semantic categories: quantificationand definiteness/indefiniteness. The research conducted in the second half of the $20^{\text {th }}$ century in integrational linguistics serves as a starting point for the discussion (and consequently, it is reasonable to refer to generative semantics, the "meaning - text" theory and functional grammar).

At the core integrational depiction, linguists recognize the fact that linguistic signs are of a syncretic nature, i.e. they include meanings of several semantic functions which thereby "come into contact with one another" within a sign, which leads to a more or less regular cooperation. Moreover, implicational forms were noted: the meaning of category $F$ included in sign $A$ qualifies the meaning of category $G$ (Kiklewicz 2004: $44 \mathrm{ff}$.).

A belief (in the spirit of B. Russell's theory of descriptions) widespread among the reference theory researchers about the determined meaning of uniqueness and about the undetermined meaning of existential quantification, can serve as an example of such an 
implication. In a similar manner, exponents of the definiteness/indefiniteness category were assigned to quantificational meanings ${ }^{1}$.

While agreeing, as a matter of principle, with the theoretical foundations of the integrational linguistics, in particular functional grammar, the author is nevertheless of the opinion that such an approach should not contradict the fact of functional identity, or distinctiveness, of specific semantic categories. Consequently, such research tools should be used to expose the areas in the language system where semantic categories form oppositions (and demonstrate their distinctive features) as well as the areas of their mutual relations (co-occurrence, convergence, divergence, implication, etc.).

The author realizes that he is referring in this paper to linguistic issues dating back to the past century, which have been discussed in multiple publications. This attempt is justified by the fact that, in the first place, the issues of extensional semantics have not lost their validity (although they are discussed from a more pragmatic perspective, see von Fintel 2008). Secondly, the author is convinced of the need to revise certain statements and "truths" of the referential theory, which gained popular, conventionalized characteristics, and which, in fact, do not fit in the language system or the linguistic activity when it is described objectively, and not in the spirit of constructivism - through extrapolation of logical semantics category.

The structure of the paper has been organized along this leading idea. Points 2 and 3 present the contemporary state of research in reference theory, in particular the so-called model of definiteness based on quantification. In Point 4, numerical quantification is described as a particular type of quantitative determination of nominal groups. In Point 5 , the author shows the differentiated character of the category of definiteness, in particular, distinguishing the determinacy of a descriptive nature and of an epistemic nature. Definiteness as a distributional quantification condition is emphasized. Points 6 and 7 demonstrate to what extent the meaning of definiteness/indefiniteness is implied by quantification measures, as well as how existential quantification is expressed through undetermined pronouns as a result of semantic derivation (polysemy). Four aspects of such dependencies: selection, implication, collocation and derivation, are examined in the paper using Polish language materials and materials of other European languages.

2. Intensive linguistic research on quantification was performed in the second half of the 20th century, which was the reign generative semantics, modal and intensional semantics, and the theory of reference. Quantification was mostly examined in functional terms - in light of interaction with other categories, such as determination, definiteness/ indefiniteness, reference (referential status of nominal groups), and (to a lesser extent) collectivity, quantity/number, gradation and valuation.

As a result of these studies, there was a slight blurring of the category of quantification, which began to be treated as a kind of referential determination (or actualization). Linguists followed the logical semantics of Alfred Tarski, especially his conception of

${ }^{1}$ A certain justification of such an interpretation is the fact that determinants and quantifiers are treated as functional categories in opposition e.g. to adjectives as a lexical category, according to the terminology proposed by A. Radford (2004: 37). 
fulfilment and assignment, according to which the use of quantifiers allows the transformation of an open proposition into a closed one, i.e. a sentence marked with respect to truthfulness/falsity (Tarski 1948: 39 ff.; Sgall 1986: 74-75; Burdman Feferman \& Feferman 2009: 143; Antonelli \& May 20102 ff.). The core of a referential model of quantification is a belief that quantifying words are only used with object variables, they cannot create nominal groups (NGs) with single names which deserve the status of referential names:

(1) *every Alexander the Great

(2) *every he

(3) *every the only best friend ${ }^{2}$

On this basis, it was claimed that quantifiers are a class of operators of a referential status of (indeterminate) NG. It resulted in blurring the boundaries between such semantic categories as quantification, reference, determination and definiteness. The renowned Italian Slavist Francesca Giusti stated: "Quantification applies to such names of objects whose participation in a situation cannot be determined within an act of speech" (1982: 4). Similar statements are found in the publications of many other researchers: Grzegorczykowa 1987: 133; Karolak 1990: 121; Palek 1965: 258 ff.; Weiss 1977: 242 ff. and others. In accordance with the radical opinion of Renata Grzegorczykowa, the notion of 'quantification' should be abandoned and substituted with the notion of 'reference' (1992: 273; 1995: 120 ff.).

In this way, the researchers seem to have succumbed to the prevailing trend, not realizing the inconsistency of such statements with the facts of linguistic activity. The analysis shows that the referential model of quantification does not fit the linguistic material. For instance, in the sentence:

(4) Zrobił wrażenie na ws zystki ch. Zauważyłem też, że ci ws zys cy, mniej lub bardziej otwarcie, zaczęli zerkać w moją stronę (PELCRA $\left.{ }^{3}\right)$; 'He made an impression on everyone. I also noticed that all those people started, more or less openly, looking in my direction'.

there is a generalizing (quantifying) pronoun wszystkich 'everyone' in a position of object. The pronoun does not refer to 'all the people' as an open set. The speaker means a limited known to him (and presumably the receiver as well) set of the people who were impressed on. In the second part of the utterance there is NG, namely, ci wszyscy 'those everyone' which directly refers to the people whose participation in the situation (contrary to the statement by Giusti) is determined within the speech act ('the people who were made impression on'). ${ }^{4}$ Elżbieta Wierzbicka-Piotrowska (2011: 32) reasonably notes

${ }^{2}$ The impossibility of similar collocations is explained by the fact that the NG is not collective; quantifying words are applied only to collective names (see: Byeong-uk Yi 2005; 2016).

${ }^{3}$ http://www.nkjp.uni.lodz.pl.

${ }^{4}$ One of specific examples can be the qualifier oba/obaj/obie/oboje 'both'. Zuzanna Topolińska (1984: 320) notes that in constructions with this lexeme "two-element collectivity is present as an identified argument". Even earlier, in 1969, it was described by Adam E. Suprun and in his opinion oba 'both' operates as 
that the partial (existential) quantifiers connect with the definite descriptions as well as with the generic nouns.

A determined status of $\mathrm{NG}$ as a quantification object is not necessarily expressed through a lexical operator, since a context also plays an important role in this respect. For instance, as results from the analysis by J. Stanley \& Z. G. Szabó (2000: 231), the sentence

(5) Every bottle is empty.

does not mean that every existing bottle is (out of its nature) empty, but that (in the communicative situation analysed by the researchers) all bottles bought by Lisa for Max (and which are the subject of conversation known to both interlocutors) are empty.

3. To some extent categories of quantification and definiteness were merged as well (see: Sawicka 1978: 55). Scholars have offered a model of definiteness based on quantification (Polish: kwantyfikacyjny model określoności) (Koseska-Tosheva 1990: 33 ff.; see also: Barnetová 1979: 366; Hlavsa \& Svozilová 1969: 123). The meaning of singularity was treated as definite, while meanings of general and partial quantification were treated as indefinite. In this regard, the researchers follow Bertrand Russell's theory of descriptions, according to which (semantically) non-singular nouns have an indefinite denotative status. However, this proposition is not true for collective nouns which can have a definite denotative status, see the following:

(6) these books

(7) these two pedestrians

(8) my parents

These NG (with a definite referential status) can be an object of quantitative determination, e.g.:

(9) all these books

(10) both of these pedestrians

(11) both of my parents ${ }^{5}$

Another approach consists in the fact that the exponents of definiteness/indefiniteness, such as articles, are considered exponents of quantification, namely, meanings of existence (Giusti 1982: 7; Schwinn 1989: 82; Stechow 1991: 42). For example, in the German sentence:

(12) Ein Mann schläft.

an analogue of expression wszystkie $d w a$ 'all both', i.e. having a function of qualifying pronouns of deictic nature: in constructions $o b a x$ 'both $\mathrm{x}$ ' it is assumed that previously mentioned objects are referred to (Suprun 1969: 37).

${ }^{5}$ There exists a phenomenon referred to as "floating quantifiers" (see: Bobaljik 2003; Kobuchi-Philip 2007; Cirillo 2012 etc.), for instance, in the sentences: All the students have read the book; The students have all read the book. Irrespective of preposition or postposition, the quantifier is located within the area affected by a specific noun group (NG). 
the meaning of existential quantification might be found: $\exists x P(x)$, as in the sentences with quantifiers of the following type:

(13) Einige Männer sind schrecklich falsch.

However, at the same time, it does not get pointed out that in the first case the NG is of a singular nature, while in the second case the NG is of a collective nature. The possibility of existential interpretation of the sentence itself is not enough because the existence is not equal to quantification. Sentence (13) is about the presence of a certain number (a subclass) of men (against a background of the initial class of persons who are men) who share the property of being false. In other words, the quantifier einige informs that a class of men who are false is a part of a class of men. In sentence (12), this information is not present, so it cannot be treated in a similar manner: 'There is at least one man (in a set of men) who (at the moment) is sleeping'.

A reference to the initial set of elements (in the case of quantification) does not allow the use of the NG of the type "quantifier + noun" in the predicate position, whereas NGs with an article take this position with no limitations:

(14) Das ist ein Mann.

(15) *Das sind einige Männer.

It seems to indicate that articles and quantifiers belong to different semantic categories (an alternative point of view: Vater 1984).

What is more, it should be noted that the position of the predicate is not conductive to an existential interpretation of the NG with an article. Thus, sentence (13) cannot be translated as ${ }^{*}$ 'There is a man, such that it is him'. ${ }^{6}$

In languages without articles, these are demonstrative and indefinite pronouns which are interpreted in terms of quantification: the former (e.g. this, here, then) are equated with the exponents of singularity and the latter are treated as the exponents of existence (Grzegorczykowa 1976: 193; Hlavsa 1975: 15).

4. The meaning of quantification can be determined in the semantics of NGs regardless of the use of any quantifying operators. Compare the sentences:

(16) All scientists / the scientists should care about the results of their research beingspread.

(17) As soon as Saturday comes all the scientists are moving out from the library.

The former (16) is about scientists in general, the scope of consideration includes all existing scientists. In the sentence (17), the scope of consideration is narrower: it refers to a subclass of scientists known to the speaker. This kind of quantification, i.e. 'refer-

${ }^{6}$ For this reason, Isaak I. Revzin (1978: 165) criticized identification of quantification and definiteness claiming that articles have a (not cognitive) communicative meaning and are assigned to several communicative situations. The quantitative meaning of a definite article can be formed as a result of eliminating the communicative factor, i.e. as a result of semantic derivation. We are dealing with this phenomenon, for example in the sentences with the general meaning: Der Löwe ist ein Raubtier; Die Menschen sind sterblich. 
ential quantification' by S. Karolak (1989) or 'status quantification' has a latent character in Slavonic languages ${ }^{7}$ : it is not expressed with specialized quatifying words (Kiklewicz 2009: 46).

A class of generalizing and indefinite pronouns, such as everyone, all, always, some, sometimes, anyone etc., as well as other lexical and grammatical means (majority, minority, part, whole etc.) serve to express numerical quantification. ${ }^{8}$ It is one of the three categories of quantitative determination of collective NG (namely actual determination). In my previous works (Kiklewicz 2001: 124; 2009: 46), I defined those types in the following way: 1) nominal determination - with reference to an arithmetic norm; 2) gradual determination - with reference to a situational norm; 3) actual determination - with reference to an existential norm. ${ }^{9}$ The three types of quantitative semantics can be illustrated with the following sentences:

(18) Adam ate three apples 'The number of apples eaten by Adam is equal to the model set which consists of three elements'.

(19) Adam ate many apples 'The number of apples eaten by Adam is higher than the number of apples (or anything else) that are usually eaten by a man of his age or are usually eaten by Adam'.

(20) Adam ate all the apples 'The number of apples eaten by Adam is equal to the number of apples which were available for Adam to eat (which existed in that situation)'.

Quantification meanings are realized in two cognitive models: completeness and existence. The first model is represented in formal logic and it is based on the relation of scopes of concepts: $\mathrm{SaP}, \mathrm{SiP}, \mathrm{SoP}, \mathrm{SeP}$. In mathematical logic the meaning of completeness is indicated by a general (universal) quantifier:

$$
\begin{aligned}
& \forall \mathrm{x} \text { P (x) } \\
& \forall \mathrm{x} \neg \mathrm{P}(\mathrm{x}) \\
& \neg \forall \mathrm{x} \text { P (x) } \\
& \neg \forall \mathrm{x} \neg \mathrm{P}(\mathrm{x})
\end{aligned}
$$

There is also another way of categorizing knowledge about the range of a set of elements participating in the referential situation in mathematical logic, based on the concept of existence: ${ }^{10}$

$$
\begin{aligned}
& \exists \mathrm{x} \text { P (x) } \\
& \exists \mathrm{x} \neg \mathrm{P}(\mathrm{x}) \\
& \neg \exists \mathrm{x} \mathrm{P}(\mathrm{x}) \\
& \neg \exists \mathrm{x} \neg \mathrm{P}(\mathrm{x})
\end{aligned}
$$

${ }^{7}$ In the English language, a difference occurs at the formal-grammar level of the sentence: all scientists/ all the scientists, which figure in examples (16) and (17).

${ }^{8}$ For quantification as a quantitative category see: Nozsicska 1978: 211; Shikhare \& Heim/Klein et al. 2015: 1505 .

9 "The NP argument provides the domain of the quantifier, and the Q expresses a relation between this set and the set denoted by the VP" (Etxeberria \& Giannakidou 2008)

${ }^{10}$ From a logical point of view, anexistential quantifier is equivalent to the information that a set of elements with property $P(x)$, is not empty (see: Antonelli \& May 2010: 12). 
It should be noted that, in terms of extensionality, both types of categorization are congruent, however they have different perspectives on intensional conceptualization of the same states of things. The difference can be shown visually.

A

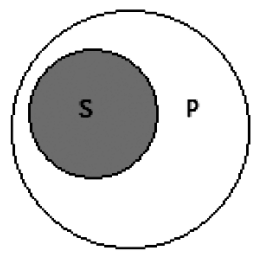

I

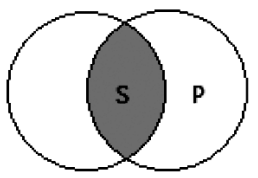

O

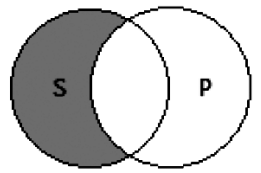

E

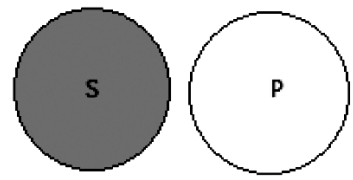

Figure 1. Completive quantification
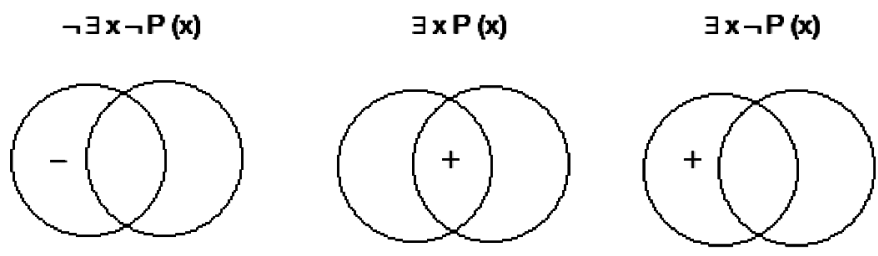

$\neg \exists \mathbf{x} \mathbf{P}(\mathbf{x})$

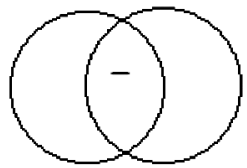

Figure 2. Existential quantification

The differences between the two models of quantification are indicated by relations of negation. In the first model, particular affirmative propositions are the negation of universal affirmative propositions (Not every $S$ is $P \rightarrow($ Only) some $S$ are $P$ ) and particular negative propositions are the negation of universal negative propositions (No $S$ is $P \rightarrow$ $($ Only) some $S$ are not $P$ ), while in the case of existential quantification these relations are radically different:

$$
\begin{aligned}
& \mathrm{A}=\neg \mathrm{O} \\
& \mathrm{E}=\neg \mathrm{I}
\end{aligned}
$$

Information about the same range of participation of a certain set of objects in a referential situation can be expressed in the completive model or in the existential model, see:

(21) Anyone can substitute you. [completive quantification]

There is no one that could not substitute you. [existential quantification] 
(22) Not everyone can understand it. [completive quantification]

Only some can understand it. [completive quantification]

There are some who cannot understand it. [existential quantification] ${ }^{11}$

Completive quantification is of a more direct nature since the meaning of a general quantifier includes the concept of a set: 'for every $x$ from the set...', while the existential quantification is indirect and (from the standpoint of quantity) less specified: an operator of existence can also be used with reference to singular nouns: 'there is (one such) $x$ which...' This is important information concerning diagnostic transformations, i.e. ones that are used to determine the presence or absence of quantification in the meaning of exponents of other semantic categories. First, for this purpose, collective operators should be used. The possibility of an appropriate transformation indicates that we are dealing with the presence of quantification, see:

(23) Die Menschen sind sterblich.

(24) Es hatte ein Mann einen Esel.

The first sentence can be assigned to the interpretation involving a general quantifier: 'All people are mortal', however in the second case it is not possible: the interpretation 'every man' or 'not every man' would be inappropriate here. Interpretation by the use of an existential operator ('There was/existed a man who had a donkey') does not have anything in common with quantification in the sense it does not include determination of a collective NG in terms of relation between the range within the predicate and the initial range.

5. Neither definiteness nor indefiniteness can be reduced to a single opposition of meanings. Elena V. Paducheva (1985; see also Kobozeva 2000: 231) distinguished the NGs with two referential statuses: indefinite and underdetermined (Russian слабоопределенные). Previously, this opposition was described by Zuzanna Topolińska (1984: 313). The former (e.g. Polish pronouns with $-s$ ', such as ktoś 'someone', jakiś 'some', coś 'something' etc.) are of an e pistemic nature, they express a lack of knowledge about the referent of the NG (see: Sokolova/Makarova 2011). The latter (jeden $x$ 'one $x^{\prime}$, pewien $x^{\prime}$ a certain $x^{\prime}$ ) are of determinative/descriptive nature, they indicate the incompleteness of information about the referent, for example:

(25) A certain merchant bought three crossbows and four wands.

'There existed/was one (as one being) merchant who bought three crossbows and four wands;

I am not saying which merchant he was (except that it was a merchant);

It does not necessarily mean that I do not know anything about this merchant'.

In the latter case we are dealing with a situation in which the recipient does not expect or require canceling indefiniteness, which makes it impossible to assign interrogative sentences to indefinite pronouns (Arutyunova 1995: 184).

${ }^{11}$ As we can see, the particular affirmative proposition in the model of completeness is extensionally equal to the particular negative proposition in the existential model. 
The existence of these two functional classes should be taken into account when reflecting on the relationship between quantification and determination. One aspect of this relationship concerns the distributional (or selective in another terminology) properties of quantifying words related to the meanings of definiteness and indefiniteness. In this respect, quantification is marked: quantifiers require connectivity with collective NG of a definite nature. On the one hand, collocations with semantics of oc casional definiteness are unlimited (Krylov 1984: 140): in the position of the right collocate at a quantifying word there can be, for example, a personal pronoun as a typical exponent of a specific denotative status, cf.:

(26) Znalazł się w ogromnym zielonym pomieszczeniu, pełnym pary wodnej, błyszczących kafli, kranów, luster i nagich mężczyzn. Niektórzy z nich siedzieli na niskich stołeczkach wzdłuż rzędu kranów wystających z kafelkowanej ściany (PELCRA) 'He found himself in a huge room full of water vapor, shining tiles, taps, mirrors and naked men. Some of them were sitting on low stools along the row of taps protruding from a tiled wall'.

The fact that the object of quantification is known to the speaker is expressed by the phenomenon of contextual substantivization (see: Suprun 1969: 28; Chesnokova 1992: 45). Let us consider a piece of artistic prose:

(27) Weszła właśnie z ogrodu, a ja siedziałam przy stole i robiłam porządek w torebce. Ściśle biorąc, szukałam w niej małej karteczki z nazwą środka przeciwko grzybnej zarazie, ale żeby znaleźć małą karteczkę, musiałam wyrzucić w s zys tko (PELCRA) 'She just came in from the garden and I was sitting at a table and was clearing out my handbag. Strictly speaking, I was looking for a small piece of paper with the name of a medication against a fungal infection, but to be able to find a piece of paper I had to throw everything out'.

Wszystko 'everything' does not mean here 'all existing objects/things' but 'all the things in my bag': an initial set of objects is determined occasionally: the speaker sees or remembers the things located in the bag.

On the other hand, the object of quantification can be determined permanent$1 \mathrm{y}^{12}$ when a collective NG refers to a generic set of objects with a defined feature included in a lexical notion:

(28) - Nie wszyscy lekarze są rzetelni - żali się czterdziestolatek, który raz skorzystał z takiej pomocy (PELCRA) '- Not all doctors are reliable - complained a forty-year-old man who used such aid once'.

The range of consideration (and the range of quantification) includes here a generic class of (all existing) doctors, and the text lacks any indications that this class might be limited in any way. Each element of this set is known to be a doctor.

12 Consequently, P. Dieveney (2014) examines quantification as an element of metaphysical discourses. 
Claiming that quantification assumes a referential status of NGs (determined in terms of quantity) may seem quite unusual since the NGs like lekarz 'doctor' in the theory of reference (according to the tradition founded by Bertrand Russell) are commonly regarded as indefinite descriptions. This is true, but in this case we are dealing with a plural noun lekarze 'the doctors', which radically changes the situation. As long as the description lekarz 'doctor' (singular) should be considered indefinite and underdetermined, in the sense that there is a certain number of doctors, calling somebody a doctor is not enough to distinguish a specific person from the general public; the description lekarze 'doctors' (plural) has a different status: now the identity of the set is ensured by indicating the quality of 'being a doctor' as well as the supposition that there is only one class/ category of objects that are doctors. Therefore, the description lekarze 'doctors' (plural) is not accompanied by indefinite semantics (or experience of indefiniteness from a psychological point of view). This is why (see: Kiklewicz 2009: 45) in (at least in some) languages with articles, plural noun forms are not preceded by indefinite articles, cf. English the child, a child - the children, *a children.

The definiteness of plural nouns is indirectly indicated by Topolińska (1984: 320). Acknowledging that only in the case of argument expressions in the form of coordinate structures (based on conjunction), such as John, May and Paul, the collective referent is represented by specific (identified) elements, the researcher also considers argument expressions in plural forms as definite:

[...] A collective argument expression in plural form interpreted as such presents the collectivity without distinguished elements, designated and identified in appropriate context only as a whole (Topolińska 1984: 320).

It should be also noted that in the right position, quantifiers do not take collective NGs which would be indefinite in the epistemic sense, in other words, such NGs (bound with a quantifier) cannot include indefinite pronouns, see:

(29) *Every some doctor is reliable. / *All some doctors are reliable.

6. In the previous section, I considered the distributional aspect of the relation of quantification and definiteness/indefiniteness. There remains a question of configuring these categories in the content of means of quantification - quantifying words. When it comes to the exponents of general (universal) and partial (existential) quantification, they do not provide the lexical meaning of the $\mathrm{NG}$ with any new conceptual information (except for quantitative information) which would allow for exemplary identification of a set of elements taking part in the described situation; information deals only with the fact that this set overlaps with the initial one or it does not. At the same time, it cannot be argued that the meaning of descriptive indefiniteness (or any other) is expressed in that way. In the case of a general quantifier, the statement that all the elements of a certain, pre-defined set take part (or they do not) in the situation is enough to have knowledge of the nature of that set. If the speaker knows about these books (for example, because they were mentioned before), then the sentence:

(30) All these books share a critical analysis of communism. 
leaves no doubt as to the fact that the set of books that share a critical analysis of communism is congruent with the set of these books. ${ }^{13}$ When a quantifier connects with a generic $\mathrm{NG}$, an utterance is not accompanied by any problematical character (Szubka 2009: 111).

It is different in the case of partial quantification: a set of elements covered by the predicate is not full, but at the same time there is no specification for this subset: operators such as część 'part', niektórzy/niektóre 'some', mniejszość 'minority', czasem 'sometimes' etc. are too imprecise in order for the current range of reference to be considered definite ${ }^{14}$. For instance, the sentence:

(31) Thorns of some sea urchins have fabulous shapes.

lacks information about the differences between sea urchins whose thorns have fabulous shapes and other sea urchins. As Wierzbicka-Piotrowska (2011: 32) writes, in this case a nominal group gets the "value of crypto-definiteness".

Therefore, the question arises, whether - conversely - exponents of indefiniteness (epistemic and descriptive ones) express a partial quantification. Thus, let us consider two sentences:

(32) Mother superior has already received certain funds.

(33) Mother superior has already received part of (the)funds.

Both sentences show a high degree of probability. Anyway, the two of them can be transformed as follows: 'There are funds that mother superior has already received'. However, the difference is that the exponent of quantification such as part or some refers to the initial set of elements (the set of funds that mother superior was supposed to receive), indicating that part of that set participates in the situation described with this sentence. This information excludes the possibility of general quantification (only part of the funds and not all of them) or allows for it (at least part of the funds and perhaps / it is not impossible that all of them). It needs to be emphasized, once again, that the quantifying meaning amounts to quantitative (numerical) information.

In the case of the exponent of underdetermination/indeterminacy such as certain information about the initial set of elements is not present: the speaker only says that what

13 This is why I think it is groundless to include exponents of general quantification in the class of indefinite pronouns (wszyscy 'all', zawsze 'always', wszelki 'any' etc.), for example, as suggested by Wierzbicka-Piotrowska (2011: 86). Topolińska leaves no doubt as to the fact that quantification and indefiniteness constitute separate semantic categories. In her newest article a Polish researcher writes that quantifying pronouns "refer to the entire range of a named set of denotations of a given concept", while indefinite pronouns are described by her in the following way: "In the time sphere of the present and the past they refer to objects that exist, but are unidentified to the sender of the message, in the sphere of the future - to virtual objects" (2016: 38). At the same time, Topolinska states there is a common denominator for these classes, namely, the semantics of NG references.

14 This is the case described by Topolińska: "Names of sets, otherwise designated as identified ones, in appropriate contexts and with a substantial size of the set may have any undefined sets consisting of elements in these sets as referents" (1984: 320). 
mother superior received are funds which are not described/specialized (for example their amount). The operator certain does not assume connectivity with particles:

(34) * She received at least certain funds (and perhaps all the funds).

(35) *She received only certain funds (or parts of them) (not all the funds).

7. Partial quantification, as noted, implies indeterminacy but it is not about indefiniteness in epistemic terms, i.e. ignorance. Certain $S$ are / are not $P$ does doesn't mean 'I do not know which S are / are not P', and vice versa, exponents of epistemic indefiniteness (ktoś 'somebody', coś 'something', gdzieś 'somewhere' and other) do not express partial quantification. In sentences like:

(36) In front of the house there is some boy.

The NG boy has a singular status, so there cannot be any quantification. But in the case of collective NGs, such as the one in the following sentence:

(37) Some boys are standing in front of the house.

there is information about the fact that the speaker has no knowledge of the referent of the NG, except that it is a limited group of boys. Possible transformation: "There are boys, those who are in front of the house' is not sufficient to claim the partial quantification. In the sentence:

(38) In front of the house there are certain boys.

we are dealing with a different state of things: it is about participation in the situation of part of a group of boys which the speaker knows something about. See a variant of this sentence:

(39) In front of the house there are some of the boys (from among those who had to come).

Indefinite pronouns may also appear in the meaning of detailed quantification as a result of semantic derivation. In similar cases, certain syntactic (positional) conditions need to be met: firstly, the pronoun takes the thematic position of the utterance (moving it to a hematic position gives it a meaning of indefiniteness ${ }^{15}$ ); secondly, a quantitative use of an indefinite pronoun is usually done in a coordinated construction: in this way, a subset of elements participating in situation $A$ is opposed to a subset of elements participating in situation $B$. The quantitative nature of the use of a pronoun in similar constructions is indicated by the possibility to substitute it with a typical exponent of quantification - pronoun niektórzy/niektóre 'some', see a few illustrations found on the Internet (www.google.pl):

${ }^{15}$ A communicative/informative structure of sentences with exponents of definiteness (in particular, such categories as theme/rheme, topic/focus etc.) deserves more extensive analysis (see: Herburger 2000; Ott 2012), but it would go beyond the limitations of this paper. 
(40) Ktoś z moich przyjaciół został w kraju, a ktoś wyjechał. 'Some of my friends have stayed in the country and some have left'.

(41) Tak wiec jak to jest, że ktoś może, a ktoś nie? 'So, how is it possible that someone can and someone cannot?'

(42) Ktoś odchodzi, ktoś przychodzi. 'Someone leaves, someone comes'.

(43) Ktoś odbiera, a ktoś daje. 'Someone takes away, someone gives'.

For example, the last sentence does not mean 'I do not know who takes away and who gives', in fact its content includes quantitative information: 'There exist people (from the set of people being considered) who take away, and there exist people (from the set of people being considered) who give'.

The theory of reference which was popular in the last decades of the 20th century resulted in a lot of new information about so-called 'small words', mostly pronouns, articles, particles, conjunctions, etc. These units were considered not only as exponents of separate semantic categories, but also as a kind of continuum of syncretic forms which constitute an area of contact and intermingling of different functions. Coming up with certain solutions, linguists seem to have 'gone too far', wrongly interpreting some categories in light of the others. Reism (particularly criticized by Cezar Piernikarski, see 1990: 43) which is specific to the theory of reference contributed to the withdrawal and oblivion of proven methods of verifying paradigmatic identity developed by structural linguistics. For example, the criterion of distribution makes it possible to distinguish linguistic forms belonging to different semantic categories in an objective way which is linguistically-oriented and, at the same, time it is independent of logical or psychological reasons:

(44) all of them / they all

(45) none of them

(46) some of these changes

(47) these two ladies / both these ladies

(48) each of the poems

(49) always then

(50) *some both ladies

(51) *some all men

(52) *every none actor

In constructions (44)-(49) we are dealing with the contrastive distribution: exponents of different semantic categories have a certain common reach. The fact that two lexical units can occur in the same position, in the same syntactic environment shows that they represent different linguistic categories.

As regards sentences (50)-(52), their incorrectness can be explained in the simplest way by using the concept of complementary distribution: two units cannot occupy the same position at the same time (co-occur) due to the fact that they represent alternative meanings of the same function, i.e. a quantifying function. Thus, we cannot combine in one structure any alternates, e.g.: 
(53) *new old house

(54) *five thirteen apples

(55) *come back late early

Relations between quantification and determination in four aspects: selection, implication, collocation and derivation, can be presented in a synthetic way as follows.

Figure 3. Quantification vs determination: four aspects

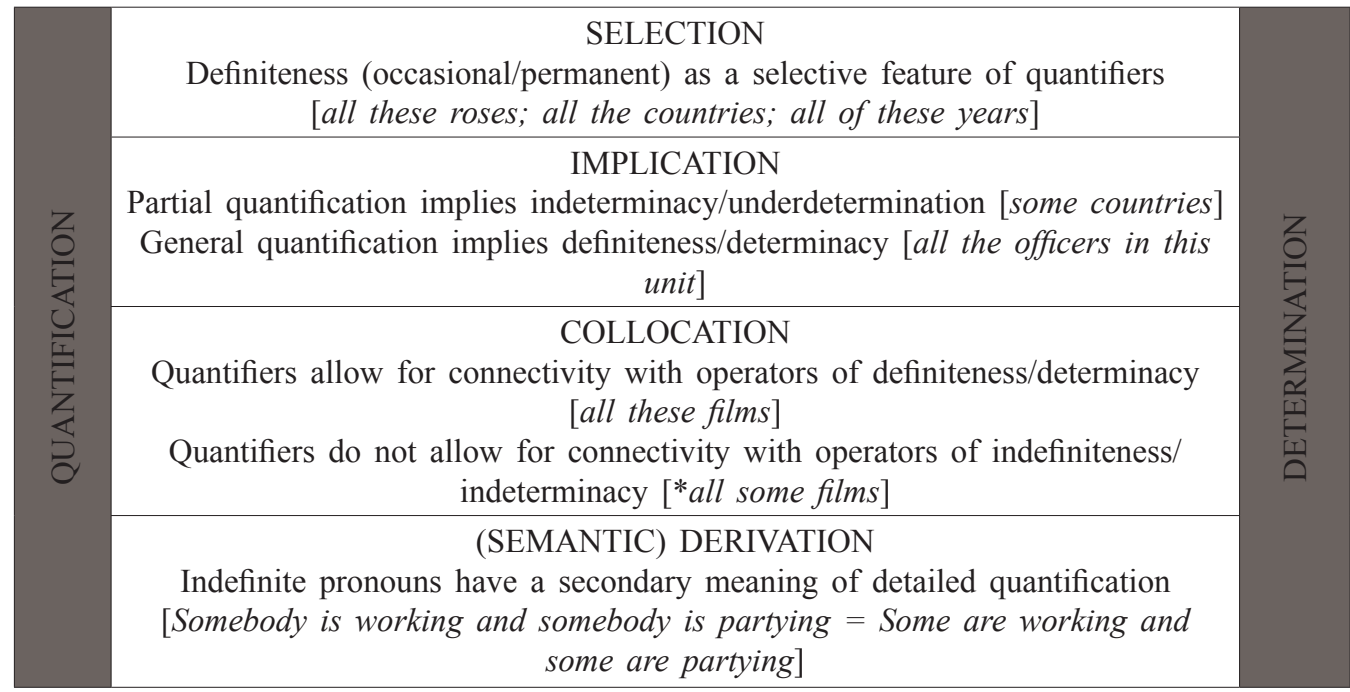

As we can see, the relationship between quantification and definiteness is too complex and multi-faceted in order to offer a simple and straightforward solution. Certainly, the information I have presented in this article needs to be complemented. However, there is no doubt that in the description of similar phenomena, the principle of dialectical contradiction (cf. German der dialektische Gegensatz) should be followed. One needs to acknowledge that linguistic categories are internally diversified and their general structure is of a radial (field) type. Therefore, from one perspective, they have indigenous characteristics which determine their identity and values in the system of language while, from another, more pragmatic perspective, there are different kinds of interactions with other categories.

\section{References}

Antonelli, G. Aldo \& May, Robert C. 2010. Quantifiers and Determiners. In: Russell, Gillian \& Graf Fara, Delia (eds.), The Routledge Companion to the Philosophy of Language, 1-15. New York, London: Routledge. Arutyunova, Nina D. [= Арутюнова Н. Д.]. 1995. Неопределённость признака в русском дискурсе. In: Арутюнова, Н. Д. (ед.), Логический анализ языка: Истина и истинность в культуре и языке, 182-189. Москва: Наука. 
Barnetová, Vilma. 1979. Русская грамматика, 1. Praha: Academia.

Bobaljik, Jonathan D. 2003. Floating quantifiers: handle with care. In: Cheng, Lisa \& Sybesma, Rint (eds.), The Second GlotInternational State-of-the-Article Book, 107-148. Berlin, New York: Mouton de Gruyter.

Byeong-uk, Yi. 2016. Quantifiers, Determiners and Plural Constructions. In: Carrara, Massimiliano \& Moltmann, Friederike \& Arapinis, Alexandra (eds.), Plurality and Unity: Philosophy, Logic and Semantics, 3-78. Oxford: University Press.

Byeong-uk, Yi. 2005. The logic and meaning of plurals. Part I. Journal of Philosophical Logic 34. 459-506.

Burdman Feferman, Anita \& Feferman, Solomon. 2009. Alfred Tarski: życie i logika. Warszawa: Wydawnictwa Akademickie i Profesjonalne.

Chesnokova, Lidia D. [= Чеснокова, Л. Д.]. 1992. Категория количества и способы ее выражения. Таганрог: Издательство Таганрогского университета.

Cirillo, Robert. 2012. A Fresh Look at the Debate on Floating Quantifiers. Language and Linguistics Compass 6/12. 796-815.

Dieveney, Patrick. 2014. Quantification and Metaphysical Discourse. Theoria 80. 292-318.

Etxeberria, Urtzi \& Giannakidou, Anastasia. 2008. Contextual domain restriction across languages: Determiners, quantifiers, and the structure of QP; http://www.iker.cnrs.fr/IMG/pdf/etxebe\%26giannaki2009.pdf (Accessed: 5.03.2017).

Fintel, Kai von. 2008. What is presupposition accommodation, again? Philosophical Perspectives 22. 137-170.

Giusti, Francesca. 1982. Неопределенные показатели имени нарицательного. Russian Linguistics 7/1. 3-19.

Grzegorczykowa, Renata. 1976. Aktualizacja wypowiedzi poprzez kwantyfikację argumentów i predykatu. Otazkyslovanské syntaxe IV/1. 195-200.

Grzegorczykowa, Renata. 1987. Zaimki uogólniające a mechanizmy tworzenia zdań ogólnych. Прилози. Од деление за лингвистикаи литературна наука XII/2. 133-140.

Grzegorczykowa, Renata. 1992. Problemy dyskusyjne w opisie zjawiska referencji. In: Banyś, Wiesław \& Bednarczuk, Leszek \& Bogacki, Krzysztof (eds.), Etudes de linguistique Romane et Slave, 271-281. Cracovie: Ecole Normale Superieure.

Grzegorczykowa, Renata. 1995. Funkcje modalne niektórych zaimków nieokreślonych we współczesnej polszczyźnie. In: Grochowski, Maciej (ed.), Wyrażenia funkcyjne w systemie i tekście, 143-149. Toruń: Wydawnictwo UMK.

Herburger, Elena. 2000. What Counts. Focus and Quantification. Cambridge, London: The MIT Press.

Hlavsa, Zdeněk. 1975. Denotace objektu a jeji prostředky v současné češtině. Praha: Academia.

Hlavsa, Zdeněk \& Svozilová, Nad’a. 1969. K povazevýznamu u zájmen. Slovo a slovesnost XXX. 120-124.

Karolak, Stanisław. 1989. Kwantyfikacja referencyjna a kwantyfikacja numeryczna. Studia Gramatyczne Butgarsko-polskie 3. 7-26.

Karolak, Stanisław. 1990. Kwantyfikacja a determinacja w językach naturalnych. Warszawa: PWN.

Kiklewicz, Aleksander [= Киклевич, А.]. 1995. Review: Косеска-Тошева, В. \& Гаргов, Г., Българско-полска съпоставителна граматика. 2. Семантична категория определеност/неопределеност. София 1990. Славяноведение 2. 110-111.

Kiklewicz, Aleksander [= Киклевич, А.]. 1998. Язык и логика. Лингвистические аспекты квантификации. München: Otto Sagner Verlag.

Kiklewicz, Aleksander [= Киклевич, А.]. 2001. Количество и юмор. In: Kiklewicz, Aleksander (ed.), Quantität und Graduierung in der natürlichen Sprache, 123-148. München: Otto Sagner Verlag.

Kiklewicz, Aleksander. 2004. Podstawy sktadni funkcjonalnej. Olsztyn: Wydawnictwo UWM.

Kiklewicz, Aleksander. 2009. Kwantyfikacja a determinacja. O jednym micie logiczno-semantycznym. In: Mańczak, Witold \& Wawrzyńczyk, Jan (ed.), Prawda - prawdy - mity - fałsze w językoznawstwie, 37-51. Warszawa: Takt.

Kobozeva, Irina M. [= Кобозева, И. М.]. 2000. Лингвистическая семантика. Москва: Наука.

Kobuchi-Philip, Mana. 2007. Floating numerals and floating quantifiers. Lingua 117(5). 814-831.

Koseska-Tosheva, Violeta \& George Gargov [= Косеска-Тошева, В. \& Гаргов Г.]. 1990. Българско-полска съпоставителна граматика. 2. Семантична категория определеност/неопределеност. София: Издателство БАН.

Krylov, Sergei A. [= Крылов, С. А.]. 1984. Детерминация имени в русском языке: теоретические проблемы. Семиотика и информатика 23. 124-154.

Nozsicska, Alfred. 1978. Bemerkungen zur Quantifikation, Konjunktion und Negation im Russischen. Wiener Slawistischer Almanach 2. 209-239. 
Ott, Dennis. 2012. Local Instability. Split Topicalization and Quantifier float in German. Berlin, Boston: De Gruyter.

Paduczeva, Elena W. [= Падучева, Е. В.]. 1985. Высказывание и его соотнесенность с действительностью (референциальные аспекты семантики местоимений). Москва: Наука.

Palek, Bohumil. 1965. Zajímavé podněty pro lingvistickou sémantiku. Slovo a slovesnost XXVI. 250-262.

Piernikarski, Cezary. 1990. Struktura syntaktycznych grup homogenicznych (w zestawieniu z niektórymi typami grup heterogenicznych). Wrocław etc.: Ossolineum.

Radford, Andrew. 2004. English Syntax. An Introduction. Cambridge.

Revzin, Isaak I. [= Ревзин, И. И.]. 1978. Структура языка как моделирующей системы. Москва: Наука.

Sawicka, Irena. 1978. Referencijalna kvantifikacija rečenice. Зборник за филологију и лингвистику XXI, s. $55-61$.

Schwinn, Michael. 1989. Semantische Interpretation syntaktischer Kategorien und die Zeichentheorie von C. S. Peirce. Heidelberg. [Dissertation.]

Sgall, Petr et al. 1986. Úvod do syntaxe a sémantiky. Praha.

Shikhare, Sailee \& Heim, Stefan \& Klein, Elise et al. 2015. Processing of Numerical and Proportional Quantifiers. Cognitive Science 39. 1504-1536.

Sokolova, Svetlana \& Makarova, Anastasia [= Соколова, С./Макарова, А.]. 2011. Что-то как-то непонятно: типология контекстов дискурсивного употребления местоимений; https://iling.spb.ru/confs/rusconstr2011/ materials/SokolovaMakarova_handout.pdf (Accessed: 20.05.2016).

Stanley, Jason \& Gendler Szabó, Zoltan. 2000. On Quantifier Domain Restriction. Mind \& Language 15/2-3. 219-261.

Stechow von, Arnim (ed.). 1991. Semantik. Ein internationales Handbuch der zeitgenössischen Forschung. Berlin, New York: De Gruyter.

Suprun, Adam E. [Супрун, А. Е.]. 1969. Славянские числительные. Становление числительных как части речи, Минск: Вышэйшая школа.

Szubka, Tadeusz. 2009. Filozofia analityczna. Koncepcje, metody, ograniczenia. Wrocław: Wydawnictwo Uniwersytetu Wrocławskiego.

Tarski, Alfred [= Тарский, А.]. 1948. Введение в логику и методологию дедуктивных наук. Москва: Издательство иностранной литературы.

Topolińska, Zuzanna. 1984. Składnia grupy imiennej. In: Topolińska, Zuzanna (ed.), Gramatyka współczesnego języka polskiego. Składnia, 301-386. Warszawa: PWN.

Topolińska, Zuzanna. 2016. Zaimki - uniwersalny system referencji. LingVaria XI/1. 35-41.

Vater, Heinz. 1984. Determinantien und Quantoren im Deutschen. Zeitschrift für Sprachwissenschaft 3/1. 19-42.

Weiss, Daniel. 1977. Syntax und Semantik polnischer Partizipialkonstruktionen. Bern etc.: Peter Lang.

Wierzbicka-Piotrowska, Elżbieta. 2011. Polskie zaimki nieokreślone. Wybrane zagadnienia semantyczne, syntaktyczne i pragmatyczne. Warszawa: Wydawnictwo Uniwersytetu Warszawskiego.

Ziembiński, Zygmunt. 1978. Logika praktyczna. Warszawa: PWN. 